\title{
OPEN Citral modulates virulence factors in methicillin-resistant Staphylococcus aureus
}

\author{
Hellen Braga Martins Oliveira ${ }^{1}$, Nathan das Neves Selis ${ }^{1}$, Beatriz Almeida Sampaio ${ }^{2}$, \\ Manoel Neres Santos Júnior ${ }^{1}$, Suzi Pacheco de Carvalho ${ }^{1}$, Jéssica Bomfim de Almeida ${ }^{1,2}$, \\ Palloma Porto Almeida ${ }^{3}$, Icaro Bonyek Santos da Silva ${ }^{4}$, Caline Novais Teixeira Oliveira ${ }^{1,2}$, \\ Thamara Louisy Santos Brito ${ }^{2}$, Letícia de Oliveira da Silva ${ }^{2}$, Mariana Morais Teixeira ${ }^{2}$, \\ Hanna Izadora Laís Novaes Coelho², Camila Dutra Barbosa², Yasmin Monara Ferreira de \\ Sousa Andrade ${ }^{4}$, Rafaela de Souza Bittencourt' ${ }^{2}$, Jully Chayra Santos Viana², \\ Guilherme Barreto Campos ${ }^{2}$, Jorge Timenetsky ${ }^{5}$, Ana Paula T. Uetanabaro ${ }^{1}$, \\ Regiane Yatsuda ${ }^{2} \&$ Lucas Miranda Marques ${ }^{1,2 \bowtie}$
}

Methicillin-resistant Staphylococcus aureus (MRSA) is responsible for high morbidity and mortality rates. Citral has been studied in the pharmaceutical industry and has shown antimicrobial activity. This study aimed to analyze the antimicrobial activity of citral in inhibiting biofilm formation and modulating virulence genes, with the ultimate goal of finding a strategy for treating infections caused by MRSA strains. Citral showed antimicrobial activity against MRSA isolates with minimum inhibitory concentration (MIC) values between $5 \mathrm{mg} / \mathrm{mL}(0.5 \%)$ and $40 \mathrm{mg} / \mathrm{mL}(4 \%)$, and minimum bactericidal concentration (MBC) values between $10 \mathrm{mg} / \mathrm{mL}(1 \%)$ and $40 \mathrm{mg} / \mathrm{mL}(4 \%)$. The sub-inhibitory dose was $2.5 \mathrm{mg} / \mathrm{mL}(0.25 \%)$. Citral, in an antibiogram, modulated synergistically, antagonistically, or indifferent to the different antibiotics tested. Prior to evaluating the antibiofilm effects of citral, we classified the bacteria according to their biofilm production capacity. Citral showed greater efficacy in the initial stage, and there was a significant reduction in biofilm formation compared to the mature biofilm. qPCR was used to assess the modulation of virulence factor genes, and icaA underexpression was observed in isolates 20 and 48. For icaD, seg, and sei, an increase was observed in the expression of ATCC 33,591. No significant differences were found for eta and etb. Citral could be used as a supplement to conventional antibiotics for MRSA infections.

Staphylococcus aureus is an important and potentially lethal opportunistic pathogen. These bacteria have high virulence and the ability to acquire resistance mechanisms and pathogenic characteristics. S. aureus is normally associated with various infections acquired in the community and in hospitals ${ }^{1-3}$.

Widespread and indiscriminate use of antibiotics can lead to the selection and antimicrobial resistance of bacterial isolates. The detection of antibiotic-resistant pathogens is relevant for therapeutic purposes, as well as to prevent the spread of resistant strains ${ }^{4}$. The $S$. aureus strain resistant to almost all $\beta$-lactam antibiotics, determined by a chromosomal gene mecA that encodes altered PBPs (PPB2a or PBP2'), is referred to as methicillin-resistant Staphylococcus aureus (MRSA) and can be found in hospital settings (HA-MRSA), as well as in the community $(\mathrm{CA}-\mathrm{MRSA})^{5}$. Infections caused by these bacteria are linked to higher mortality rates and higher treatment costs for an overburdened health system compared to infections caused by strains of $S$. aureus sensitive to methicillin $(\mathrm{MSSA})^{6-8}$.

The virulence potential of different isolates of $S$. aureus is determined by the presence or absence of virulence genes that encode staphylococcal enterotoxins (ses), Panton-Valentine leukocidin ( $p v l$ ), exfoliatins (eta and etb),

\footnotetext{
${ }^{1}$ Universidade Estadual de Santa Cruz, Rod. Jorge Amado, Km 16, Salobrinho, Ilhéus, Bahia 45662-900, Brazil. 'Instituto Multidisciplinar em Saúde, Universidade Federal da Bahia, Rua Hormindo Barros, 58, Candeias, Vitória da Conquista, Bahia 45029-094, Brazil. ${ }^{3}$ Departamento de Biologia Geral, Universidade Federal de Viçosa, Av. Peter Henry Rolfs S/N. Campus Universitário, Viçosa, Minas Gerais CEP 36570-000, Brazil. ${ }^{4}$ Instituto Gonçalo Muniz, Fundação Oswaldo Cruz, Rua Waldemar Falcão, 121, Candeal, Salvador, Bahia 40296-710, Brazil. ${ }^{5}$ Instituto de Ciências Biomédicas, Universidade de São Paulo, Avenida Professor Lineu Prestes, 2415, Butantã, São Paulo 05508-900, Brazil. ${ }^{\varpi}$ email: Imirandamarques@gmail.com
} 


\begin{tabular}{|l|l|l|l|}
\hline Isolates & MIC $(\mathbf{m g} / \mathbf{m L})$ & MBC $(\mathbf{m g} / \mathbf{m L})$ & Subinhibitory dose $(\mathbf{m g} / \mathbf{m L})$ \\
\hline 18 & 10 & 20 & 2.5 \\
\hline 20 & 10 & 40 & 2.5 \\
\hline 27 & 10 & 10 & 2.5 \\
\hline 33 & 20 & 20 & 2.5 \\
\hline 48 & 10 & 10 & 2.5 \\
\hline 52 & 40 & 40 & 2.5 \\
\hline 80 & 5 & 40 & 2.5 \\
\hline 137 & 5 & 20 & 2.5 \\
\hline ATCC 33591 & 10 & 10 & 2.5 \\
\hline
\end{tabular}

Table 1. MIC, MBC, and subinhibitory dose values for isolates of MRSA treated with citral. MIC minimum inhibitory concentrations, $M B C$ minimum bactericidal concentrations.

hemolysins, and other exotoxins. These genes provide bacteria with the ability to infect and colonize ${ }^{9,10}$, resulting in food poisoning and other types of infections in humans and animals.

Because of bacterial resistance, a better understanding of the factors involved in the pathogenicity of S. aureus is important for developing alternative treatments. Thus, the choice of antibiotics for treating infections caused by this microorganism is limited ${ }^{11}$. In the search for an alternative to antibiotics, natural products have been studied, including essential oils. Essential oils are volatile secondary metabolites composed of complex mixtures of organic substances, characterized by a strong odor, and formed in response to stressors. These substances feature actions such as passage through a cell wall and plasma membrane, which can affect the cytotoxic properties of bacterial structures, in addition to presenting therapeutic protective properties against oxidation and deterioration processes caused by microorganisms ${ }^{12-14}$.

Among the major components extracted from the removal of essential oils from edible aromatic plants, citral (3,7-dimethyl-2,6-octadienal) is a natural mixture of geranial (trans-citral) and neral (cis-citral), which are two acyclic monoterpenic aldehydes and isomers, found in a variety of plants, such as in melissa (Melissa officinalis), lemongrass (Cymbopogon citratus), and verbena (Verbena officinalis) ${ }^{15,16}$.

Various studies have shown the antimicrobial activity of components of essential oils, such as citral, on strains of $S$. aureus, inhibiting biofilm formation or altering virulence factors. It is known that essential oils and major components can act to deregulate virulence genes, in addition to antibacterial, antifungal, analgesic, antispasmodic, and antiparasitic activities, in addition to fighting nerve disorders ${ }^{15,17,18}$. Despite the antibacterial properties of this oil against gram-positive and gram-negative bacteria, its prolonged use has not shown resistance ${ }^{19,20}$.

In a previous study, we analyzed the anti-inflammatory action of citral using an air pouch model in 48 male $\mathrm{BALB} / \mathrm{c}$ mice infected and/or treated with citral. A positive effect was observed in reducing the microorganism, in addition to a significant decrease in the levels of TNF- $\alpha$ in mice treated with citral ${ }^{21}$. Thus, this study considers a new therapeutic alternative for infections triggered by MRSA, analysing the effect of citral on the antimicrobial effect of antibiotics, inhibition of biofilm formation, and modulation of the expression of virulence factors. This study is not only relevant but pertinent, as there are few studies involving citral and MRSA.

\section{Results}

The minimum inhibitory concentration (MIC) and minimum bactericidal concentration (MBC) data are listed in Table 1 . The lowest concentration that inhibited bacterial growth was $5 \mathrm{mg} / \mathrm{mL}(0.5 \%)$, whereas the highest concentration was $40 \mathrm{mg} / \mathrm{mL}$ (4\%). The bactericidal concentrations varied between $10 \mathrm{mg} / \mathrm{mL}(1 \%)$ and $40 \mathrm{mg} /$ $\mathrm{mL}(4 \%)$. Of the nine MRSA strains tested, five showed the same concentration in both tests. Using the growth curve, it was possible to determine the concentration that would decrease bacterial growth but would not kill the isolates. After defining MIC and MBC, the subinhibitory concentration of citral was determined to verify the modulation of virulence factors without affecting the viability of microorganisms. Therefore, tests were performed with the concentrations $40 \mathrm{mg} / \mathrm{mL}(4 \%), 20 \mathrm{mg} / \mathrm{mL}(2 \%), 10 \mathrm{mg} / \mathrm{mL}(1 \%), 5 \mathrm{mg} / \mathrm{mL}(0.5 \%), 2.5 \mathrm{mg} /$ $\mathrm{mL}(0.25 \%), 1.2 \mathrm{mg} / \mathrm{mL}(0.12 \%)$, and $0.6 \mathrm{mg} / \mathrm{mL}(0.06 \%)$, with a concentration of $2.5 \mathrm{mg} / \mathrm{mL}$ being determined for achieving the curve (Table 1).

The analysis of modulating activity was compared with the Clinical \& Laboratory Standards Institute (CLSI) manual (2020), with the following resistance halos: $\leq 28$ for ampicillin, $\leq 15$ for ciprofloxacin, $\leq 14$ for clindamycin, $\leq 13$ for erythromycin, $\leq 21$ for oxacillin, and $\leq 14$ for tetracycline. The inhibition zone $(\mathrm{mm})$ and fractional inhibitory concentration were measured after $24 \mathrm{~h}$ of incubation. Our results showed that $5 \mathrm{mg} / \mathrm{mL}(0.5 \%)$ citral was able to modulate the antimicrobial activity of different antibiotics through synergistic, antagonistic, or indifferent actions. In the inhibition zone $(\mathrm{mm})$, the results were statistically significant for strain 80 with ciprofloxacin, for strains 52 and 80 with the antibiotic erythromycin, strains 80 and ATCC 33591 with oxacillin, and for strain 52 with the antibiotic tetracycline $(P<0.05)$. Citral acted antagonistically with the antibiotic ampicillin for strains 52 and 80 , with the use of ciprofloxacin for strain 52, oxacillin in isolate 20, and tetracycline in isolate 18. All tested strains remained resistant to the antibiotics tested (Table 2). In the analysis of the fractional inhibitory concentration $(\mu \mathrm{g} / \mathrm{mL})$, the results were statistically significant for strain 80 for oxacillin (Table 2). Comparing the modulating effect of citral on antibiotic activity when measured via the disk diffusion and broth microdilution methods, different results were obtained. We observed that only strain 80 maintained its results 
Treatment $(\mu \mathrm{g} / \mathrm{mL})$

\begin{tabular}{|c|c|c|c|c|c|c|c|c|c|c|c|c|c|c|c|c|c|c|c|c|c|}
\hline \multirow{2}{*}{$\begin{array}{l}\text { MRSA } \\
18\end{array}$} & \multirow{2}{*}{\begin{tabular}{|l|} 
Amp \\
$0.5 \pm 0.0$
\end{tabular}} & \multirow{2}{*}{\begin{tabular}{|l|} 
Amp + citral \\
$0.5 \pm 0.0$
\end{tabular}} & \multirow{2}{*}{$\begin{array}{c}\mathbf{p} \text {-value } \\
>0.9999 \\
\end{array}$} & \multirow{2}{*}{\begin{tabular}{|l|} 
Cipro \\
$0.7 \pm 0.0$
\end{tabular}} & \multirow{2}{*}{\begin{tabular}{|l|l} 
Cipro + citral & 1 \\
$0.7 \pm 0.0$
\end{tabular}} & \multirow{2}{*}{\begin{tabular}{c|c} 
p-value \\
$>0.9999$
\end{tabular}} & \multirow{2}{*}{$\frac{\text { Clinda }}{0.8 \pm 0.3}$} & \multicolumn{2}{|c|}{ Clinda + citral p-value ${ }^{a}$} & Erytro & \multicolumn{3}{|c|}{\begin{tabular}{|l|l} 
Erytro + citral & -value \\
\end{tabular}} & \multirow{2}{*}{\begin{tabular}{|l|} 
Oxa \\
$2 \pm 0.0$
\end{tabular}} & \multicolumn{2}{|c|}{ Oxa + citral } & p-value ${ }^{a}$ & \multicolumn{2}{|c|}{ Tetra } & Tetra + citral & \multirow{2}{*}{\begin{tabular}{|c|} 
p-value \\
$>0.9999$
\end{tabular}} \\
\hline & & & & & & & & $0.7 \pm 0.3$ & 0.5185 & $2 \pm 0.3$ & \multicolumn{2}{|c|}{$2 \pm 0.3$} & $>0.9999$ & & \multicolumn{2}{|l|}{$2 \pm 0.0$} & $>0.9999$ & \multicolumn{2}{|c|}{$0.5 \pm 0.0$} & $1 \pm 0.0$ & \\
\hline 20 & $0.5 \pm 0.0$ & $0.5 \pm 0.0$ & $>0.9999$ & $1 \pm 0.0$ & $1 \pm 0.0$ & $>0.9999$ & $1 \pm 0.0$ & \multicolumn{2}{|l|}{$1 \pm 0.0$} & $2 \pm 0.0$ & $2 \pm 0.0$ & & $>0.9995$ & \begin{tabular}{l|l}
9 & $8 \pm 0.0$
\end{tabular} & $8 \pm 0.0$ & & $>0.9999$ & $1 \pm 0$ & & \pm 0.0 & $>0.9999$ \\
\hline 27 & $0.5 \pm 0.0$ & $0.5 \pm 0.0$ & $>0.9999$ & $1 \pm 0.0$ & $1 \pm 0.0$ & $>0.9999$ & $1 \pm 0.0$ & $1.3 \pm 0.0$ & .3739 & $2 \pm 0.0$ & $2 \pm 0.6$ & & $>0.9999$ & $9 \quad 8 \pm 0.0$ & $8 \pm 0.0$ & & $>0.9999$ & $1 \pm 0$ & & \pm 0.0 & $>0.9999$ \\
\hline 33 & $0.5 \pm 0.0$ & $0.5 \pm 0.0$ & $>0.9999$ & $2 \pm 0.0$ & $2 \pm 0.0$ & $>0.9999$ & $2 \pm 0.0$ & $2 \pm 0.0$ & $>0.9999$ & $2 \pm 0.0$ & $2 \pm 0.0$ & & $>0.9999$ & \begin{tabular}{l|l}
9 & $2 \pm 0.0$
\end{tabular} & $2 \pm 0.0$ & & 0.9999 & $8 \pm 0$ & & \pm 0.0 & $>0.9999$ \\
\hline 48 & $1 \pm 0.0$ & $0.8 \pm 0.3$ & 0.3739 & $1 \pm 0.0$ & $0.8 \pm 0.3$ & 0.3739 & $1 \pm 0.0$ & $1 \pm 0.3$ & 0.9999 & $4 \pm 0.0$ & $4 \pm 0.0$ & & $>0.9999$ & $5.3 \pm 0.0$ & $4 \pm 0.0$ & & 0.9999 & $1 \pm 0$ & & \pm 0.0 & $>0.9999$ \\
\hline 52 & $0.12 \pm 0.0$ & $0.5 \pm 0.0$ & $>0.9999$ & $0.5 \pm 0.0$ & $2 \pm 0.0$ & $>0.9999$ & $0.5 \pm 0.0$ & $0.7 \pm 0.0$ & .3739 & $5.3 \pm 0.0$ & $4 \pm 0.3$ & & 0.3739 & $2 \pm 2.3$ & $2 \pm 0.0$ & & 0.9999 & $2 \pm 0$ & & \pm 0.0 & $>0.9999$ \\
\hline 80 & $0.5 \pm 0.0$ & $0.5 \pm 0.0$ & $>0.9999$ & $64 \pm 0.0$ & $2 \pm 0.0$ & $>0.9999$ & $1.7 \pm 0.0$ & $1 \pm 0.0$ & .1161 & $4 \pm 0.6$ & $2 \pm 0.0$ & & $>0.9995$ & $9 \quad 64 \pm 0.0$ & $6 \pm 0.0$ & & 0.0001 & $1.3 \pm$ & 0.6 & $.8 \pm 0.4$ & 0.2508 \\
\hline 137 & $0.25 \pm 0.0$ & $0.12 \pm 0.0$ & $>0.9999$ & $2 \pm 0.0$ & $2 \pm 0.0$ & $>0.9999$ & $2 \pm 0.0$ & $2 \pm 0.0$ & $>0.9999$ & $126 \pm 0.0$ & $126 \pm$ & & $>0.9999$ & \begin{tabular}{l|l}
9 & $0 \pm 0.0$
\end{tabular} & $8 \pm 0.0$ & & 1161 & $1.7 \pm$ & 0.6 & $3 \pm 0.6$ & 0.5185 \\
\hline $\begin{array}{l}\text { ATCC } \\
33591\end{array}$ & $0.7 \pm 0.3$ & $1 \pm 0.0$ & 0.1161 & $0.5 \pm 0.3$ & $0.5 \pm 0.0$ & $>0.9999$ & $0.5 \pm 0.0$ & $0.5 \pm 0.0$ & $>0.9999$ & $126 \pm 0.0$ & $126 \pm$ & & $>0.9999$ & \begin{tabular}{l|l}
9 & $64 \pm 0.0$
\end{tabular} & $2 \pm 0.0$ & & 0.9999 & $8 \pm 0$ & & \pm 0.0 & $>0.9999$ \\
\hline & Treatmen & nt $(\mathrm{mm})$ & & & & & & & & & & & & & & & & & & & \\
\hline MRSA & Amp & Amp + citral & p-value ${ }^{a}$ & Cipro & Cipro+citral & p-value ${ }^{a}$ & Clinda & Clinda + citral & ll p-valu & $\operatorname{lue}^{a}$ & ytro & Erytro $+c$ & citral & p-value ${ }^{a}$ & Oxa & Oxa + citral & al p-valu & & Tetra & Tetra + citral & 1) p-value ${ }^{a}$ \\
\hline 18 & $1.9 \pm 0.1$ & $2.1 \pm 0.1$ & 0.1011 & $3.9 \pm 0.1$ & $3.9 \pm 0.1$ & 0.6778 & $3.9 \pm 0.1$ & $3.9 \pm 0.1$ & 0.6779 & & \pm 0.1 & $3.7 \pm 0.2$ & & 0.3295 & $3 \pm 0.0$ & $3 \pm 0.0$ & $>0.99$ & & $4 \pm 0.0$ & $3.4 \pm 0.1$ & 0.0010 \\
\hline 20 & $2.2 \pm 0.1$ & $2.5 \pm 0.1$ & 0.0390 & $3.5 \pm 0.2$ & $3.7 \pm 0.1$ & 0.2378 & $3.1 \pm 0.1$ & $3.2 \pm 0.2$ & 0.1890 & & \pm 0.1 & $3.1 \pm 0.1$ & & 0.5185 & $2 \pm 0.1$ & $1.7 \pm 0.0$ & 0.001 & & $3.5 \pm 0.3$ & $3.7 \pm 0.2$ & 0.3045 \\
\hline 27 & $1.9 \pm 0.2$ & $2.8 \pm 0.2$ & 0.1144 & $3.7 \pm 0.3$ & $3.7 \pm 0.1$ & 0.8416 & $3.3 \pm 0.3$ & $3.1 \pm 0.3$ & 0.565 & $3 \pm$ & 0.1 & $3 \pm 0.1$ & & $>0.9999$ & $1.7 \pm 0.1$ & $1.9 \pm 0.1$ & 0.0668 & & $3.5 \pm 0.2$ & \begin{tabular}{|l|l|}
$3.7 \pm 0.2$ \\
\end{tabular} & 0.2508 \\
\hline 33 & $2.4 \pm 0.1$ & $2.6 \pm 0.1$ & 0.1481 & $2.4 \pm 0.2$ & $2.6 \pm 0.1$ & 0.1890 & $2 \pm 0.2$ & $2.1 \pm 0.1$ & 0.1890 & & \pm 0.0 & $3 \pm 0.1$ & & 0.1161 & $3.1 \pm 0.2$ & $3 \pm 0.1$ & 0.3487 & & $0.9 \pm 0.1$ & $1 \pm 0.1$ & 0.1011 \\
\hline 48 & $1.5 \pm 0.1$ & $1.8 \pm 0.2$ & 0.1925 & $3.2 \pm 0.2$ & $3.7 \pm 0.3$ & 0.0290 & $3.4 \pm 0.2$ & $3.5 \pm 0.3$ & $0.028 \mathrm{~s}$ & & \pm 0.1 & $3 \pm 0.0$ & & 0.1583 & $2.1 \pm 0.2$ & $1.9 \pm 0.1$ & 0.0647 & & $3.4 \pm 0.1$ & $3.5 \pm 0.0$ & 0.1583 \\
\hline 52 & $3.3 \pm 0.1$ & $2.6 \pm 0.1$ & 0.0005 & $4.8 \pm 0.2$ & $2 \pm 0.0$ & $<0.0001$ & $4.5 \pm 0.1$ & $4 \pm 0.2$ & 0.017 & & \pm 0.1 & $2.2 \pm 0.2$ & & 0.0062 & $2.8 \pm 0.2$ & $2.2 \pm 0.1$ & 0.0120 & & $2.8 \pm 0.1$ & $3.2 \pm 0.1$ & 0.0010 \\
\hline 80 & $2.6 \pm 0.1$ & $2 \pm 0.0$ & $<0.0001$ & $0 \pm 0.0$ & $2.4 \pm 0.2$ & $<0.0001$ & $2.9 \pm 0.1$ & $3.1 \pm 0.0$ & 0.0075 & & \pm 0.1 & $3.1 \pm 0.0$ & & 0.0075 & $0 \pm 0.0$ & $2.2 \pm 0.2$ & $<0.00$ & 001 & $3.9 \pm 0.1$ & $3.9 \pm 0.2$ & $>0.9999$ \\
\hline 137 & $2.8 \pm 0.1$ & $3 \pm 0.1$ & 0.0075 & $2.6 \pm 0.1$ & $2.7 \pm 0.1$ & 0.2508 & $2.6 \pm 0.1$ & $2.7 \pm 0.1$ & 0.2508 & $0 \pm$ & 0.0 & $0 \pm 0.0$ & & $>0.9999$ & $1.3 \pm 0.2$ & $1.5 \pm 0.1$ & 0.1011 & & $2.8 \pm 0.2$ & $3 \pm 0.2$ & 0.3982 \\
\hline $\begin{array}{l}\text { ATCC } \\
33591\end{array}$ & $1.1 \pm 0.1$ & $1.4 \pm 0.1$ & 0.0158 & $4.1 \pm 0.2$ & $4.5 \pm 0.0$ & 0.0514 & $4.1 \pm 0.2$ & $4.5 \pm 0.0$ & 0.051 & $0 \pm$ & 0.0 & $0 \pm 0.0$ & & $>0.9999$ & $0 \pm 0.0$ & $2.5 \pm 0.1$ & $<0.00$ & 001 & $1.3 \pm 0.0$ & $2 \pm 0.0$ & $>0.9999$ \\
\hline
\end{tabular}

Table 2. Average of triplicate with three independent repetitions of inhibition zone $(\mathrm{mm})$ values and MIC $(\mu \mathrm{g} / \mathrm{mL})$ values for antibacterial modulating activity of citral $5 \mathrm{mg} / \mathrm{mL}(0.5 \%)$ on antibiotics ampicillin (Amp), ciprofloxacin (Cipro), clindamycin (Clinda), erythromycin (Ery), oxacillin (Oxa), tetracycline (Tet) on MRSA $(18,20,27,33,48,52,80,137)$ and ATCC 33591 strains. ${ }^{a}$ Mann-Whitney one-tailed test was used. Bold: data with statistical significance.

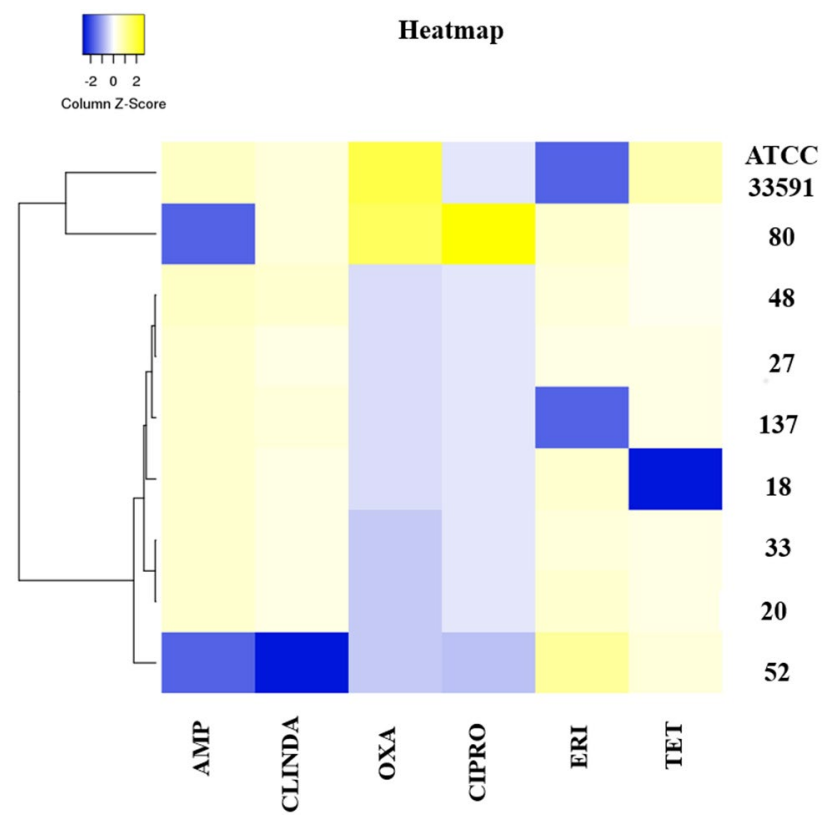

Figure 1. Heatmapper platform formed two clusters according of differential evaluation of the modulating activity at citral $5 \mathrm{mg} / \mathrm{mL}(0.5 \%)$ on antibiotics ampicillin (AMP), ciprofloxacin (CIPRO), clindamycin (CLINDA), erythromycin (ERY), oxacillin (OXA), tetracycline (TET) on MRSA (18, 20, 27, 33, 48, 52, 80, 137) and ATCC 33591 strains. The yellow segments represent greater modulation of $0.5 \%$ citral on antibiotics, and the blue segments represent less modulation.

for the antibiotic oxacillin. Based on our experiment, the checkerboard method is more sensitive for detecting synergy and disk-diffusion may serve as an initial screening method for the detection of potential synergies. 

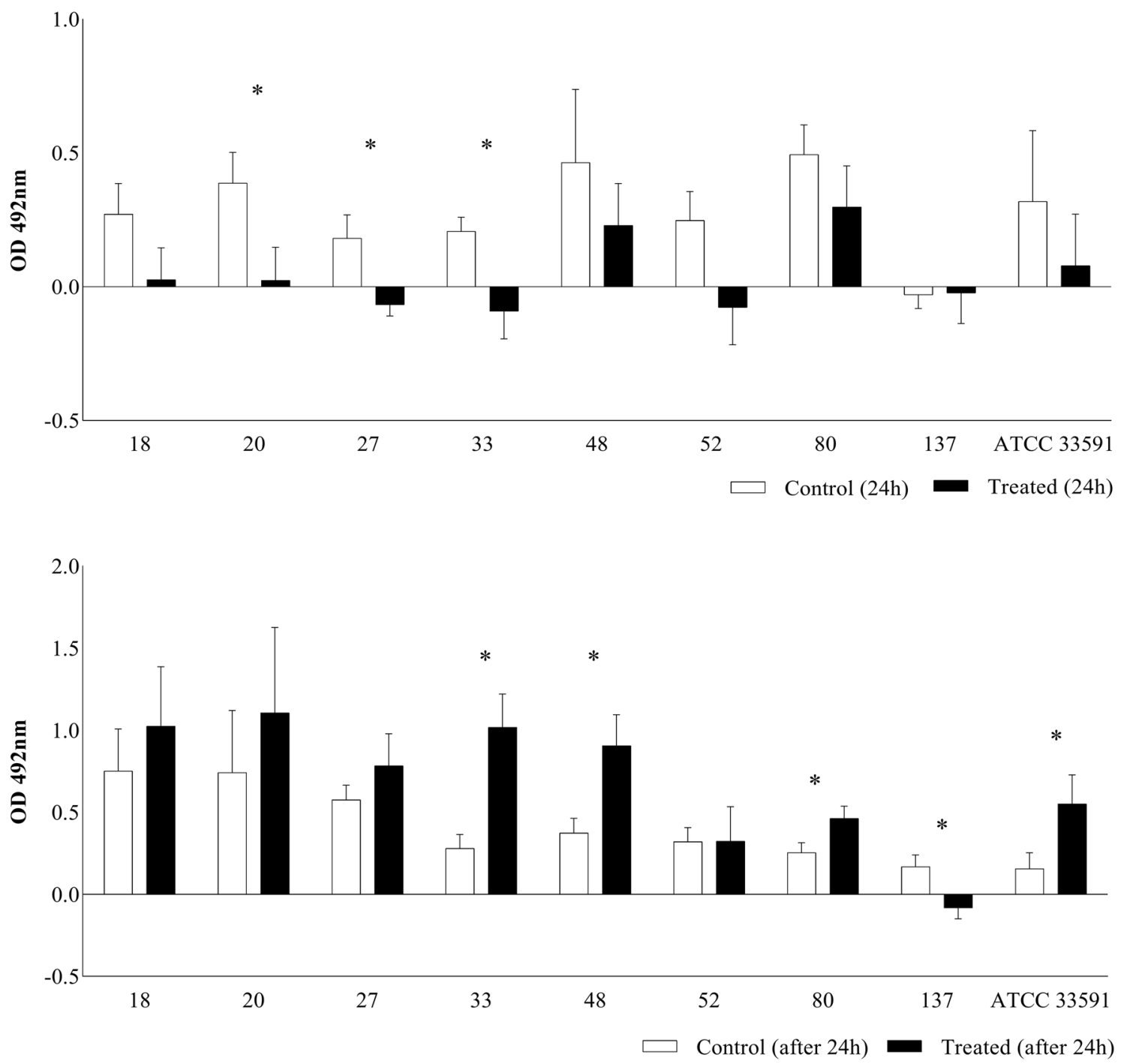

Figure 2. Biofilm formation capacity of the MRSA strains (18, 20, 27, 33, 48, 52, 80, 137) and ATCC 33591 control treated with $25 \mathrm{mg} / \mathrm{mL}$ (2.5\%) citral for $24 \mathrm{~h}$ and with the addition of $2.5 \%$ citral after $24 \mathrm{~h}$ of the formed biofilm represented in a quantitative way. The experiment was carried out in quadruplicate with two independent experiments. Significant difference at $P \leq 0.05\left(^{*}\right)$.

Antibiograms were also analyzed using the heatmapper platform (http://www.heatmapper.ca/expression/), and differentiated modulating activity patterns induced by different strains of MRSA were observed. The heatmap separated the isolates into three distinct clusters (cluster 1: ATCC 33591 and strain 80; cluster 2: strains 48, 27, $137,18,33$, and 20; cluster 3: strain 52) and, together with the qPCR data, showed different expression patterns induced by different strains of MRSA (Fig. 1).

Biofilm formation capacity of the MRSA were represented in a quantitative way in MRSA isolates using citral in the initial phase of biofilm formation from 0 to $24 \mathrm{~h}$, along with the addition of citral in the mature phase of the biofilm, corresponding to $24 \mathrm{~h}$ after inoculation. The concentration of $25 \mathrm{mg} / \mathrm{mL}(2.5 \%)$ of citral was more effective in isolates with citral added in the initial phase of biofilm formation than in the mature phase. In the initial phase, there was a significant reduction in biofilm formation, as isolate 20 ( $93.6 \%$ reduction), and thus isolates 27 (62.5\% reduction) and 33 (55.71\% reduction). In the mature phase, isolate 137 (51.2\% reduction) after $24 \mathrm{~h}$ of growth was the only isolate showing a positive result. Thus, it was observed that using citral in the initial phase of biofilm formation presented better results (Fig. 2).

To confirm the results of biofilm inhibition, we visualized its structural organization using confocal microscopy. Citral treatment substantially reduced $S$. aureus biomass, with a decrease in living and dead cells (Fig. 3), consistent with what was observed in the plate biofilm.

The expression of the virulence genes of the enterotoxins seg, sei, and sej of exfoliative toxins eta and $e t b$ and of genes related to the formation of the biofilm, icaA and $i c a D$, were evaluated, considering the characterization of the isolates regarding the virulence genes. Evaluation of the expression of the enterotoxin genes seg and sei (Fig. 4A,B), expression increased in the presence of citral, with significant results for strains 18 (100\% increase) and 48 (63.7\% increase) for seg, and 18 (93.4\% increase), 20 (95.1\% increase), 48 (96.8\% increase) 52 (84.5\% increase), 80 (95.9\% increase), 137 (75.8\% increase) and ATCC 33591 (98.7\% increase) for sei. None of the 


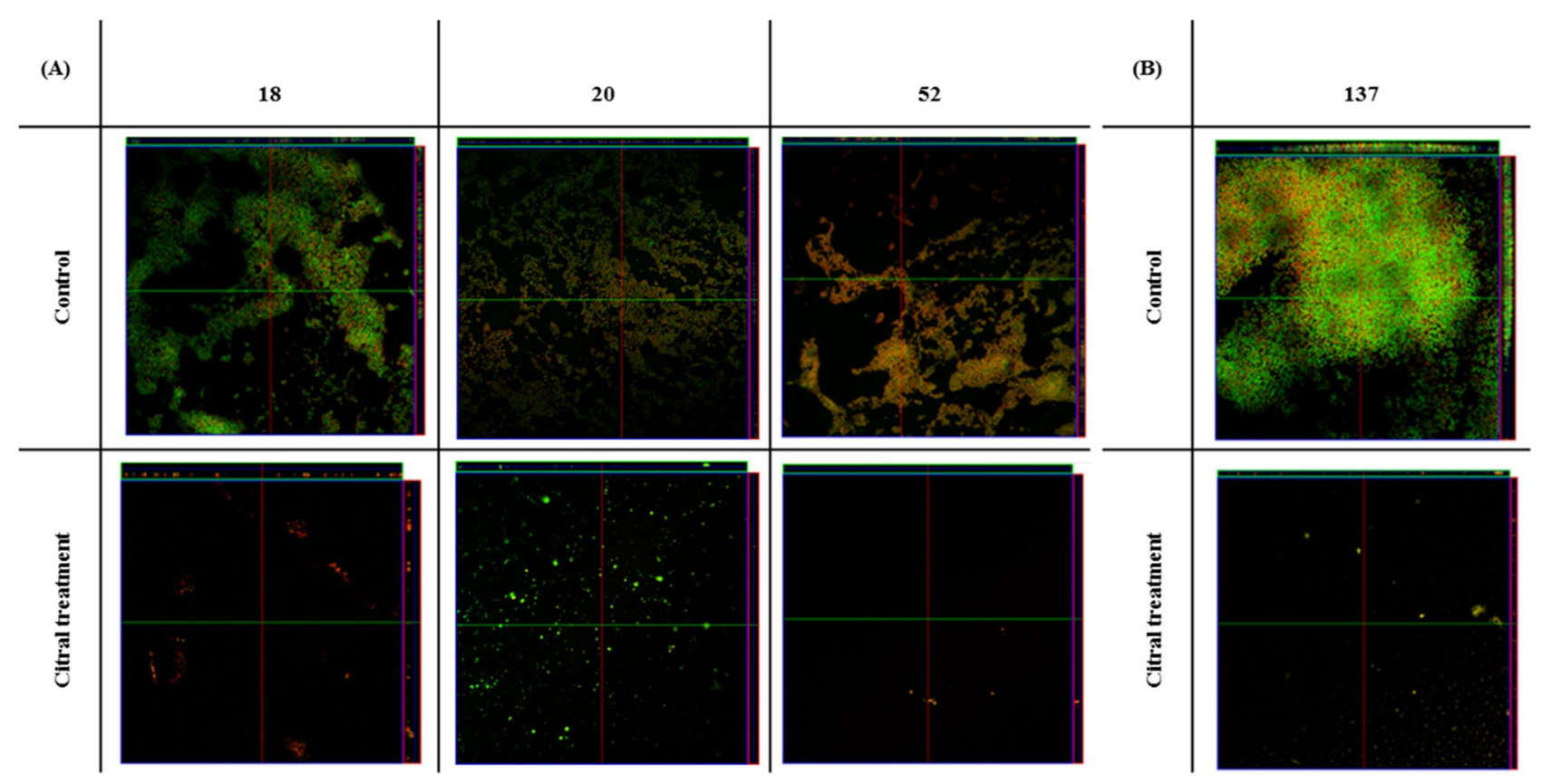

Figure 3. Confocal microscopy showing biofilm formation of isolated MRSA (18, 20, and 52) (control) and treated with citral $25 \mathrm{mg} / \mathrm{mL}$ (2.5\%) for $24 \mathrm{~h} \mathrm{(A)} \mathrm{and} \mathrm{isolated} \mathrm{MRSA} \mathrm{(137)} \mathrm{(control)} \mathrm{and} \mathrm{treated} \mathrm{with} \mathrm{citral}$ $25 \mathrm{mg} / \mathrm{mL}$ (2.5\%) for $48 \mathrm{~h} \mathrm{(B).} \mathrm{The} \mathrm{microorganisms} \mathrm{were} \mathrm{marked} \mathrm{with} \mathrm{SYTO9} \mathrm{(green)} \mathrm{and} \mathrm{unviable} \mathrm{with}$ propidium iodide (red).

MRSA strains expressed sej. For the expression of exfoliative toxin genes (Fig. 4C,D), eta and etb, no significant differences were found between the control group $(P<0.05)$. However, significant differences were found for bacteria and treatment with citral. Regarding the icaA gene (Fig. $4 \mathrm{E}$ ), the effect of citral was observed with the underexpression of two strains, 20 (79.5\% reduction), 48 (83.9\% reduction), 52 (100\% reduction), 137 (100\% reduction) and ATCC (70.3\% reduction). Isolates 20 (87.2\% reduction) and 48 (76.2\% reduction) treated with citral also showed a reduction in their control in the expression of the icaD gene (Fig. 4F). However, in the ATCC 33591 (99.8\% increase) strain, it had the opposite effect with increased expression of $i c a D$ in the presence of the treatment. The expression of virulence was also analyzed using the heatmapper platform (http://www.heatm apper.ca/expression/), and the isolates were separated into four distinct clusters (cluster 1: ATCC 33591 and 18; cluster 2: stains 80,20 , and 48; cluster 3: strain 27; cluster 4: strains 137, 52, and 33), showing differentiated expression patterns induced by different strains of MRSA (Fig. 5).

\section{Discussion}

S. aureus, MRSA, is one of the most important infectious agents because it can cause nosocomial infections, often with prolonged hospitalization, in addition to increased morbidity, mortality, and hospital costs, making bacterial resistance a major public health problem ${ }^{8,22}$. The use of natural products as microorganism control agents has been attracting interest in food and pharmaceutical sectors, as well as other fields, as pathogens associated with infectious diseases are developing resistance to commonly used drugs. Essential oils are secondary metabolites that contain hydrophobic compounds with the ability to easily diffuse through the cell wall of microorganisms, causing damage to the membrane, especially in fluidity and permeability, leading to the loss of intracellular substances and, consequently, their death ${ }^{23,24}$.

In the present study, our findings show that citral is capable of interfering with bacterial development, presenting bacteriostatic and/or bactericidal activity depending on the concentration, but the most strains and antibiotics did not show a change in antibiotic activity when citral was added. Other studies have evaluated the activity of essential oils against MRSA, including lemongrass, which has citral as one of its major components, and obtained an MIC of $0.78 \%$ and an MBC of $3.12 \%{ }^{25}$. Another study analyzed the action of citral, linalool, decanal, and valencene on $S$. aureus, diluted with Tween 80 , and observed that only citral and linalool were able to inhibit growth, with MIC values of $0.02 \%$ and $0.12 \%$, respectively ${ }^{18}$. While other authors observed lower MIC (0.03\%) and MBC (0.06\%) values with essential oils and their main components, including citral, against S. aureus $^{26}$, compared to those found in this study.

Owing to the emergence of resistance to penicillin, methicillin, and vancomycin, the options and effectiveness of antimicrobials have been reduced against $S$. aureus ${ }^{27}$. Thus, the use of natural products as microorganism control agents is relevant, since pathogens are becoming increasingly resistant to drugs used in clinical practices ${ }^{28}$. The mechanism of action of these essential oils depends on their chemical composition, and their antimicrobial activity is not the result of just one mechanism, but of various reactions that involve the entire bacterial cell ${ }^{29}$. It was observed that citral showed synergism, antagonism, or did not interfere with the antibiotic action, but the isolates remained resistant. Another study observed that the essential oil from the leaves of chemotype II 
(A)

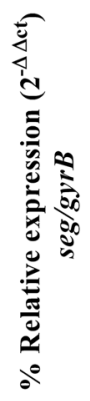

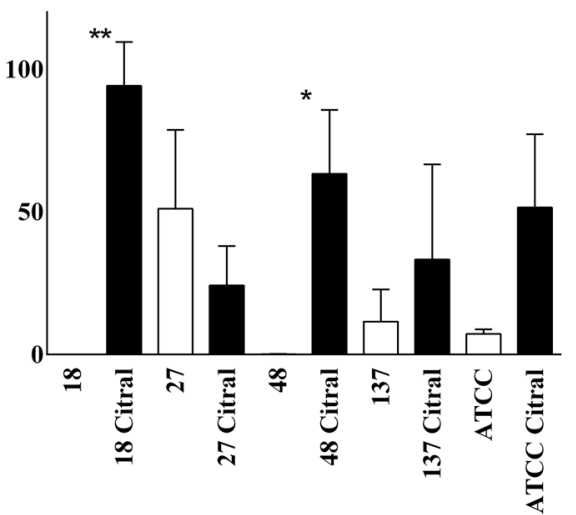

(C)

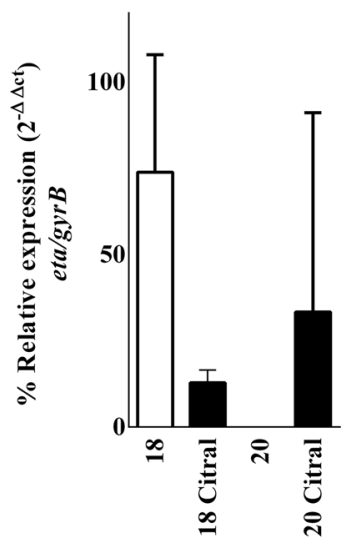

(E)

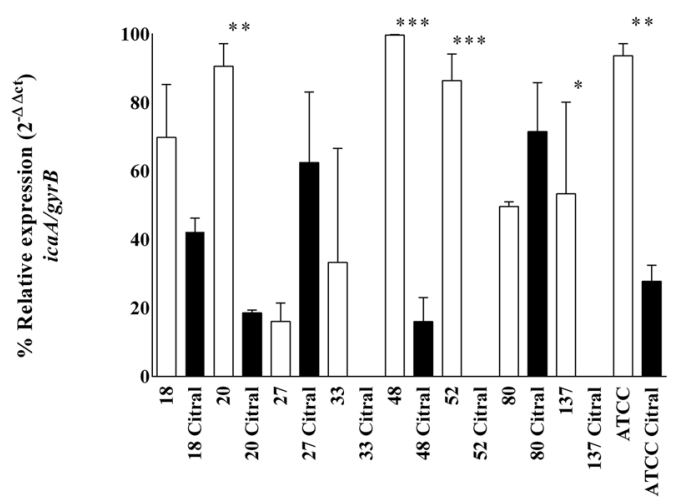

(B)

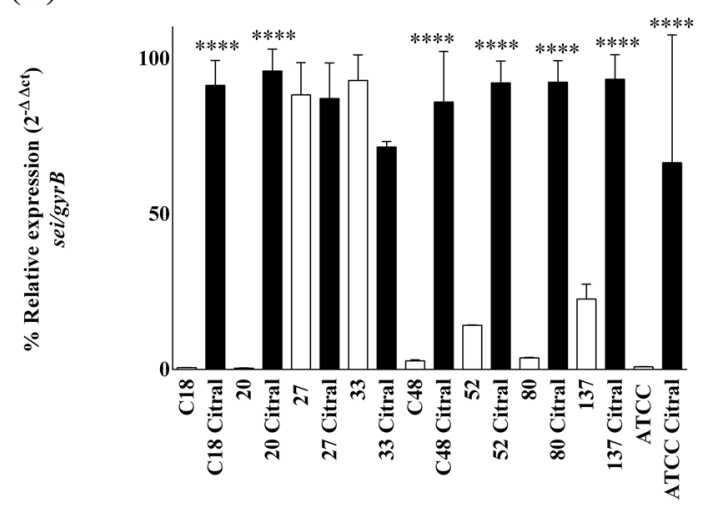

(D)

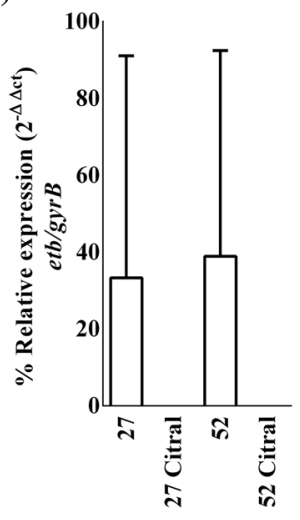

(F)

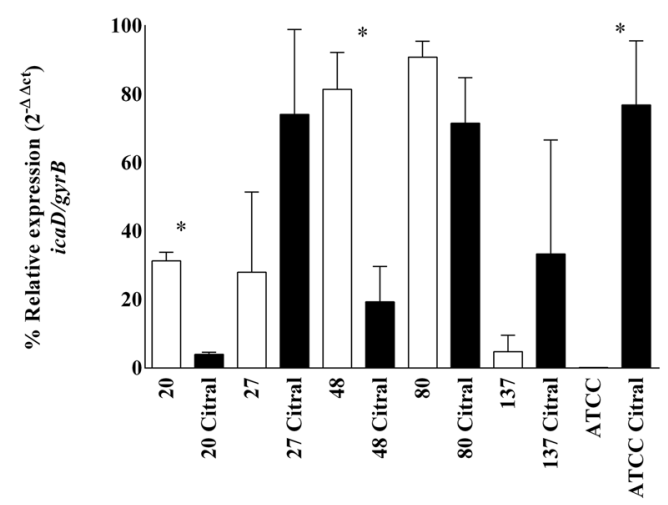

Figure 4. Relative expression of virulence genes seg (A), sei (B), eta (C), etb (D), icaA (E) and icaD (F) of the MRSA strains $(18,20,27,33,48,52,80,137)$ and ATCC 33591 control and with $25 \mathrm{mg} / \mathrm{mL}(2.5 \%)$ citral treatment. Significant difference considering $P$-value $\leq 0.05\left(^{*}\right), P$-value $\leq 0.01\left({ }^{* *}\right), P$-value $\leq 0.001\left({ }^{* *}\right)$, using Mann-Whitney one-tailed test and Kruskal-Wallis test with Dunn's test.

of Lippia alba (MILL.) can modulate the activity of the oxacillin by synergistic or antagonistic effect in MRSA strain $^{30}$. In addition, synergistic modulating activity was also observed for this essential oil with the antibiotics amikacin and clarithromycin, while it was indifferent with oxacillin, ciprofloxacin, and vancomycin or antagonist (clindamycin) when treating S. aureus ATCC $6538 \mathrm{P}^{31}$.

The effect of biofilm modulation is important because S. aureus can develop intractable infections by forming biofilms, mainly by colonizing devices such as heart valve prostheses, cardiac stimulators, contact lenses, and intravascular lines ${ }^{32}$. In general, the reduction in MRSA biofilm formation showed greater efficacy when the strains were treated with citral in the initial period of formation. The reduction of the fatty acid composition of the cell membrane and hydrophobicity are possible features of antibiofilm activity caused by terpenes, one of the components of this oil ${ }^{33}$. These components primarily target the cell wall and cytoplasmic membrane or 


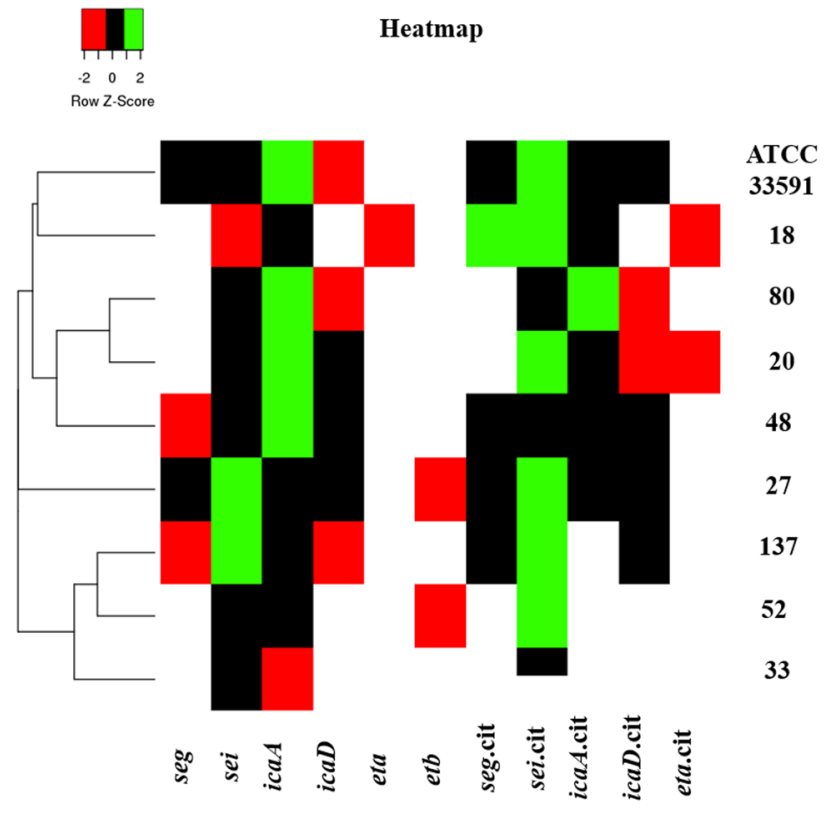

Figure 5. Heatmapper platform formed four clusters according of differentially expressed virulence genes seg, sei, icaA, icaD, eta and etb of MRSA strains $(18,20,27,33,48,52,80,137)$ and ATCC 33591 control and with $2.5 \%$ citral treatment. The green segments in the plot represent greater differential expression and the red segments represent less modulation, comparing different genes and treatment with citral.

membrane proteins, thus leading to cell death and, consequently, loss of attachment to surfaces ${ }^{34}$. Other authors have observed that sub-inhibitory concentrations of lemongrass essential oil and its major components, such as citral and geraniol, were able to significantly inhibit the biofilm formation of $S$. aureus strains isolated from subclinical mastitis, in addition to preformed biofilms ${ }^{35}$. In another study, citral inhibited biofilm formation by MRSA without affecting growth at $100 \mu \mathrm{g} / \mathrm{mL}$, while greatly hampering surface adherence ${ }^{36}$.

As in this study, the evaluation of clove and cinnamon essential oil activity under the strain of $S$. aureus ATCC 6538 , classified as strong producers of biofilm, also showed no activity on the mature biofilm ${ }^{36}$.

Furthremore, another study treating mature biofilms of S. aureus ATCC 29740, with citral at concentrations of $0.02,0.04$, and $0.08 \%$ did not report significant differences in their responses ${ }^{18}$. The induction of biofilm formation can occur in potentially toxic conditions for bacterial cells, such as high levels of osmolarity, oxidative stress, and in the presence of sub-inhibitory concentrations of possible treatments, among others ${ }^{37}$. Citral possibly has a greater effect on planktonic cells, as they are more susceptible to the action of the compound since they are not embedded in a matrix. The reduced activity of citral on the strains with mature biofilms may be related to a concentration of $25 \mathrm{mg} / \mathrm{mL}$. Furthermore, the mass production of biofilm is directly related to the incubation time ${ }^{38}$.

Studies have shown the use of essential oils against susceptible and resistant methicillin strains of $S$. aureus and their action against virulence factors ${ }^{38,39}$. The virulence potential of different $S$. aureus isolates is determined by the presence or absence of virulence genes; each bacterial strain has a unique combination of surface proteins and regulators, and they carry a variety of mobile genetic elements coding for bacterial resistance and virulence genes, indicating frequent horizontal transfer ${ }^{40}$. The $i c a A$ and $i c a D$ genes, responsible for biofilm formation, were underexpressed during citral exposure in strains 20 and 48. In strain ATCC 33591, expression of $i c a D$ (relative to the housekeeping control gene $g y r A$ ), increased on exposure to citral. These results show the effect of citral on the two isolates in the deregulation of these genes, possibly contributing to reducing pathogen virulence. The icaADBC operon encodes enzymes involved in the biosynthesis of polysaccharide intercellular adhesin (PIA) or polymeric $N$-acetylglucosamine (PNAG), which play an important role in biofilm formation. It is known that the decrease in these enzymes leads to negative regulation of $i c a A$, and consequently a reduction in biofilm ${ }^{41}$. Contrary to the results found in this study, other authors did not observe deregulation of the ica $A$ and icaD genes in S. aureus with citral activity at concentrations of $0.02 \%$ and $0.04 \%$, despite being effective for other genes ${ }^{18}$. Studies report the activity of essential oils through the quorum-sensing system, being a possible alternative for divergence and bacterial susceptibility ${ }^{42}$. It is known that in the presence of antibiotics and under certain conditions, microorganisms can present an unexpected phenotype, such as an increase in gene expression ${ }^{43}$. In the presence of citral, some isolates showed a significant difference compared to the positive control, increasing gene expression, such as in strains 18 and 48 for the seg gene, and strains 18, 20, 48, 52, 80, 137 and ATCC 33591 for the sei gene. These data suggest that the sub-inhibitory concentration of essential oil for some strains was not sufficient to act on the dysregulation of enterotoxin genes. Some studies have shown that at concentrations below the MIC, antibiotics can alter the gene expression of microorganisms causing infections, triggering a contrary response ${ }^{44}$. Another study using the essential oils of Cinnamomum zeylanicum and Ocimum basilicum observed a reduction in the expression of $s e a, s e c$, and enterotoxin genes ${ }^{45}$. Comparing the results obtained for biofilm 
structure and gene expression in MRSA 20, we noticed that after incubation with citral for $24 \mathrm{~h}$, a significant reduction in biofilm formation. This finding is consistent with the results observed in the gene expression of ica $\mathrm{A}$ and ica $\mathrm{D}$ also reduced when treated with citral (Fig. 4).

\section{Conclusion}

Our results showed that citral is also capable of modifying the biofilm produced by MRSA in the initial stage, and also exerts regulatory activity against virulence genes. It is important to emphasize the possibility of using essential oils and their major components as prophylactics or for supporting the treatment of MRSA infections, which are important for public health issues. Finally, there is a need for further studies to evaluate the activity of citral in combination with conventional antibiotics or prophylactic use, since there are few studies on the interaction between citral and MRSA.

\section{Materials and methods}

The present study selected MRSA strains (20, 27, 33, and 52) obtained from raw human milk in the Human Milk Bank of Esaú Matos Municipal Hospital located in Vitória da Conquista, Bahia, Brazil, that were used in a previous study ${ }^{46}$ and MRSA strains $(18,48,80$, and 137) isolated from nasal swabs obtained from healthy children ranging from one to six years attending daycare centers located in Vitória da Conquista, Bahia, Brazil ${ }^{47}$. The strains used were obtained from other studies approved by the Ethics Committee of Research with Human Beings of the Multidisciplinary Health Institute campus Anísio Teixeira (CAAE no. 08730012.4.0000.5556) and 08731912.5.0000.5556 (nasal strains). All methods were performed in accordance with the relevant guidelines and regulations. MRSA ATCC 33591 was obtained from a commercial source. Each sample was plated onto plates with mannitol salt agar and incubated at $37^{\circ} \mathrm{C}$ for $24 \mathrm{~h}$.

Citral. Citral was provided commercially by Sigma Aldrich. For the tests run, the citral was diluted in propylene glycol, and used in concentrations of $40 \mathrm{mg} / \mathrm{mL}(4 \%), 20 \mathrm{mg} / \mathrm{mL}(2 \%), 10 \mathrm{mg} / \mathrm{mL}(1 \%), 5 \mathrm{mg} / \mathrm{mL}(0.5 \%)$, $2.5 \mathrm{mg} / \mathrm{mL}(0.25 \%), 1.2 \mathrm{mg} / \mathrm{mL}(0.12 \%)$, and $0.6 \mathrm{mg} / \mathrm{mL}(0.06 \%)$, as recommended in the literature ${ }^{48,49}$.

Determination of minimum inhibitory concentrations (MIC) and minimum bactericidal concentrations (MBC). Bacterial suspension was prepared using a $0.9 \%$ sodium chloride solution, and the inoculum $(1 \mathrm{~mL})$ was adjusted using a spectrophotometer at $660 \mathrm{~nm}\left(1-5 \times 10^{8} \mathrm{CFU} / \mathrm{mL}\right)$. MIC tests were performed by microdilution using 96-well microplates with $190 \mu \mathrm{L}$ of the inoculum and $10 \mu \mathrm{L}$ of citral at concentrations of $40 \mathrm{mg} / \mathrm{mL}$ (4\%), $20 \mathrm{mg} / \mathrm{mL}(2 \%), 10 \mathrm{mg} / \mathrm{mL}(1 \%), 5 \mathrm{mg} / \mathrm{mL}(0.5 \%), 2.5 \mathrm{mg} / \mathrm{mL}(0.25 \%), 1.2 \mathrm{mg} /$ $\mathrm{mL}(0.12 \%)$, and $0.6 \%(0.06 \%)$, which were used as negative controls for brain heart infusion. The plates were incubated at $37^{\circ} \mathrm{C}$ for $24 \mathrm{~h}$. The MIC was considered the lowest concentration of citral, which showed no visible bacterial growth. To determine the MBC, suspensions used in the MIC test were inoculated onto BHI agar plates. All experiments were performed in triplicate with three independent repetitions ${ }^{50}$.

Determination of subinhibitory dose. To verify the modulation of virulence factors without influencing the viability of microorganisms, after the definition of MIC and MBC, the effect of a subinhibitory dose on bacterial growth was evaluated. The growth curves of MRSA alone and MRSA treated with citral at concentrations of $40 \mathrm{mg} / \mathrm{mL}$ (4\%), $20 \mathrm{mg} / \mathrm{mL}$ (2\%), $10 \mathrm{mg} / \mathrm{mL}(1 \%), 5 \mathrm{mg} / \mathrm{mL}(0.5 \%), 2.5 \mathrm{mg} / \mathrm{mL}(0.25 \%), 1.2 \mathrm{mg} / \mathrm{mL}(0.12 \%)$, and $0.6 \mathrm{mg} / \mathrm{mL}(0.06 \%)$ was performed in a closed system, with an inoculum of $1-5 \times 10^{8} \mathrm{CFU} / \mathrm{mL}$, at $37^{\circ} \mathrm{C}$. The microbial growth curve was determined every hour for $24 \mathrm{~h}$ by spectrophotometry with absorbance at $660 \mathrm{~nm}$ (Bel Photonics Spectrophotometer UV-VIS M51), and the viable cell count was determined by serial dilutions and seeding on BHI every hour ${ }^{50}$.

Evaluation of modulating activity: citral interference in antibiotics. To evaluate citral as a modulator of antibiotic action, the evaluation was performed with six antibiotics, including ampicillin $(10 \mu \mathrm{g})$, ciprofloxacin $(5 \mu \mathrm{g})$, clindamycin $(10 \mu \mathrm{g})$, erythromycin $(15 \mu \mathrm{g})$, oxacillin $(1 \mu \mathrm{g})$, and tetracycline $(30 \mu \mathrm{g})$ associated with citral $(5 \mathrm{mg} / \mathrm{mL}, 0.5 \%)$, and the lowest MIC found in the tested strains. Antibiotic susceptibility testing was performed using the disc diffusion method according to the CLSI ${ }^{51}$. The MIC value was determined according to $\mathrm{CLSI}^{51}$. The experiments were performed in triplicate with three independent repetitions.

Inhibition of biofilm formation. The ability of MRSA to form biofilms following treatment with $25 \mathrm{mg} /$ $\mathrm{mL}(2.5 \%)$ citral was analyzed according to previously proposed methods ${ }^{52}$. Biofilm assays were performed in 96-well polystyrene microplates, using trypticase soy broth (TSB/Difco) with $1 \%(\mathrm{w} / \mathrm{v})$ glucose (TSB-1\% Glc). Cultures of MRSA strains ( $5 \mathrm{~mL}$ ) were incubated in a shaker at $250 \mathrm{rpm}$ at $37^{\circ} \mathrm{C}$ for $18 \mathrm{~h}$, after which they were diluted 1:100 in TSB-1\% Glc and $200 \mu \mathrm{L}$ were inoculated into each well and incubated at $37^{\circ} \mathrm{C}$ for $24 \mathrm{~h}$. Supernatants were removed from each well and biofilms were washed twice with PBS, dried, fixed at $65^{\circ} \mathrm{C}$ for $1 \mathrm{~h}$, stained with crystal violet $1 \%$, and gently washed twice with PBS. MRSA strains were tested using citral at a concentration 10 times greater than that obtained in the subinhibitory dose $\mathrm{e}^{53}$. Two phases of biofilm formation were evaluated: early phase 0 to $24 \mathrm{~h}$ after inoculation (the period of microcolony formation) and mature phase $24 \mathrm{~h}$ after inoculation (the period after thin biofilm formation) ${ }^{54}$. The experiment was carried out in quadruplicate with two independent experiments. Biofilm production was compared to that of Streptococcus pyogenes ATCC $75194\left(\mathrm{~A}_{492 \mathrm{~nm}}=0.07\right)$. The biofilm formation index $(\mathrm{BFI})$ was calculated as follows: $\mathrm{BFI}=\mathrm{x} / \mathrm{y}$ (where " $\mathrm{x}$ " is the optical density at A492 $\mathrm{nm}$ of the biofilm and $y$ is the optical density at $492 \mathrm{~nm}$ of Streptococcus pyogenes [0.07]). Furthermore, to confirm the differences between biofilm phenotypes, confocal laser scanning 
microscopy (CLSM) was used to obtain structural images. Here, the biofilm assays were performed in the same way, but after being fixed, the bacterial cells were stained with $25 \mathrm{nM}$ SYTO9 and propidium iodide (Live/Dead Bacteria, Invitrogen, Brazil) for $15 \mathrm{~min}$ in the dark. The stain was gently removed, and biofilms were observed using a CLSM (Carl Zeiss LSM 510, Germany) equipped with an argon laser (488 nm, and 2 helium/neon $543 \mathrm{~nm}$ wavelengths) to visualize the luminescence of fluorochromes ${ }^{55}$.

Virulence factor expression modulation. To determine a possible modulating effect of citral on different virulence genes, a sub-inhibitory concentration of $2.5 \mathrm{mg} / \mathrm{mL}(0.25 \%)$ was used and incubated in a shaker at $37^{\circ} \mathrm{C}$ for $4 \mathrm{~h}$ (when all strains reached their exponential growth). Total mRNA was extracted using the PureLink $^{\text {rat }}$ RNA Mini kit (Life Technologies) and quantified by spectrophotometry (NanoDrop 2000/2000c Spectrophotometer, Thermo Fisher Scientific, Waltham, MA, US). cDNA was obtained using the SuperScript III Reverse Transcriptase Kit (Invitrogen). To detect genes related to virulence $s e c, s e i, s e j^{56}, i c a D$, ica $A^{57}$, eta and $e t b^{58}$, qPCR was used, using primers and conditions previously described. The gyrB gene ${ }^{59}$ was used as an endogenous control. This protocol included, in a final reaction volume of $27 \mu \mathrm{L}$, which included $12.5 \mu \mathrm{L}$ of SYBR ${ }^{\infty}$ Green Master Mix (Applied Biosystems), $1 \mu \mathrm{L}(13 \mu \mathrm{M})$ of each primer, $10.5 \mu \mathrm{L}$ of $\mathrm{H}_{2} \mathrm{O}$ RNAse free and $2 \mu \mathrm{L}$ of cDNA. Gene expression data were analyzed using the $2^{-\Delta \Delta \mathrm{CT}}$ method and analyzed in triplicate.

Statistical analysis. GraphPad Prism 6.0 (GraphPad Software, San Diego, CA, USA) was used for analysis. The following nonparametric tests were used: Kruskal-Wallis with Dunn's test (when evaluating more than two groups) and a Mann-Whitney one-tailed test (when evaluating two groups). Statistical differences were considered significant at $P<0.05$, using a $95 \%$ confidence interval. Citral interference in antibiotics and modulation of virulence factor expression were analyzed using the heatmapper platform (http://www.heatmapper.ca/expre ssion/) and represented as a heatmap. Unsupervised hierarchical grouping was performed using the average distance and Euclidean distance as metrics.

Ethics declarations and approval for human experiments. Ethics approval and consent were deemed unnecessary in this study, according to the Animal Ethics Committee (AEC) of the Multidisciplinary Health Institute, Federal University of Bahia. The strains used were obtained from other studies after approval by the Ethics Committee of Research with Human Beings of the Multidisciplinary Health Institute campus Anísio Teixeira (CAAE no. 08730012.4.0000.5556) and 08731912.5.0000.5556 (nasal strains). For nasal samples, informed consent was obtained from the parents or guardians.

\section{Data availability}

The datasets used and/or analyzed during the current study are available from the corresponding author upon reasonable request.

Received: 5 November 2020; Accepted: 27 July 2021

Published online: 13 August 2021

\section{References}

1. Cassettari, V. C., Strabelli, T. \& Medeiros, E. A. S. Staphylococcus aureus bacteremia: What is the impact of oxacillin resistance on mortality?. Braz. J. Infect. Dis. 9, 70-76 (2005).

2. Gelatti, L. C. et al. Sepsis due to community-acquired methicillin-resistant Staphylococcus aureus in southern Brazil. Rev. Soc. Bras. Med. Trop. 42, 458-460 (2009).

3. Brown, A. F., Leech, J. M., Rogers, T. R. \& Mcloughlin, R. M. Staphylococcus aureus colonization: Modulation of host immune response and impact on human vaccine design, Irlanda. Front. Immunol. 4, 507 (2014).

4. Ünal, N. et al. Panton-Valentine leukocidin and some exotoxins of Staphylococcus aureus and antimicrobial susceptibility profiles of staphylococci isolated from milks of small ruminants. Trop. Anim. Health Prod. 44, 573-579 (2012).

5. Stefani, S. et al. Meticillin-resistant Staphylococcus aureus (MRSA): Global epidemiology and harmonisation of typing methods. Int. J. Antimicrob. Agents 39, 273-282 (2012).

6. Gordon, R. J. \& Lowy, F. D. Pathogenesis of methicillin-resistant Staphylococccus aureus infection. Clin. Infect. Dis. 46, S350-S359 (2008).

7. Stryjewski, M. E. \& Corey, G. R. Methicillin-resistant Staphylococcus aureus: An evolving pathogen. Clin. Infect. Dis. 58(Supplement 1), S10-S19 (2014).

8. Turner, N. A. et al. Methicillin-resistant Staphylococcus aureus: An overview of basic and clinical research. Nat. Rev. Microbiol. 17, 203-218 (2019).

9. Wang, Y. et al. Effect of cinnamaldehyde and citral combination on transcriptional profile, growth, oxidative damage and patulin biosynthesis of Penicillium expansum. Front. Microbiol. 9, 597 (2018).

10. Spanu, V. et al. Virulence factors and genetic variability of Staphylococcus aureus strains isolated from raw sheep's cheese. Int. J. Food Microbiol. 153, 53-57 (2012).

11. Mendonça, E. C. L. et al. Caracterização fenogenotípica da resistência antimicrobiana em Staphylococcus spp. isolados de mastite bovina. Pesq. Vet. Bras. 32, 859-864 (2012).

12. Singh, G., Maurya, S., deLampasona, M. P. \& Catalan, C. A. N. A comparison of chemical, antioxidant and antimicrobial studies of cinnamon leaf and bark volatile oils, oleoresins and their constituents. Food Chem. Toxicol. 45, 1650-1661 (2007).

13. Bakkali, F., Averbeck, S., Averbeck, D. \& Idaomar, M. Biological effects of essential oils-a review. Food Chem. Toxicol. 46, 446-475 (2008).

14. Calo, J. R., Crandall, P. G., O’Bryan, C. A. \& Ricke, S. C. Essential oils as antimicrobials in food systems - A review. Food Control 54, 111-119(2015).

15. Dudai, N., Weinstein, Y., Krup, M., Rabinski, T. \& Ofir, R. Citral is a new inducer of caspase-3 in tumor cell lines. Planta Med. 71, 484-488 (2005).

16. Saddiq, A. A. \& Khayyat, S. A. Chemical and antimicrobial studies of monoterpene: Citral. Pestic. Biochem. Physiol. 98, 89-93 (2010). 
17. Prins, C. L., Freitas, S. P., Campostrini, E., Gravina, G. A. \& Reis, F. O. Efeitos de confinamento do sistema radicular sobre capimlimão (Cymbopogon citratus). Rev. Cien. Agronom. 39, 416-421 (2008).

18. Federman, C., Ma, C. \& Biswas, D. Major components of orange oil inhibit Staphylococcus aureus growth and biofilm formation, and alter its virulence factors. J. Med. Microbiol. 65, 688-695 (2016).

19. Irkin, R. \& Korukluoglu, M. Effectiveness of Cymbopogon citratus L. essential oil to inhibit the growth of some filamentous fungi and yeasts. J. Med. Food 12, 193-197 (2009).

20. Tyagi, A. K. \& Malik, A. Liquid and vapour-phase antifungal activities of selected essential oils against Candida albicans: Microscopic observations and chemical characterization of Cymbopogon citratus. BMC Complement. Altern. Med. 10, 65 (2010).

21. Martins, H. B. et al. Anti-inflammatory activity of the essential oil citral in experimental infection with Staphylococcus aureus in a model air pouch. Evid. Based Complement. Alternat. Med. 2017, 2505610 (2017).

22. da Silva, J. G. et al. Atividade antimicrobiana do extrato de Anacardium occidentale Linn. em amostras multiresistentes de Staphylococcus aureus. Rev. Bras. Farmacogn. 17, 572-577 (2007).

23. Valeriano, C., Piccoli, R. H., Cardoso, M. G. \& Alves, E. Atividade antimicrobiana de óleos essenciais em bactérias patogênicas de origem alimentar. Rev. Bras. Plant. Med. 14, 57-67 (2012).

24. Pu, S., Wang, F. \& Ge, B. Characterization of toxin genes and antimicrobial susceptibility of Staphylococcus aureus isolates from Louisiana retail meats. Foodborne Pathog. Dis. 8, 299-306 (2011).

25. Sroiphetcharat, S., Sukplang, P. \& Thongmee, A. In vitro investigation of antimicrobial activity of essential oil against methicillin resistant Staphylococcus aureus (MRSA). BHST 15, 63-70 (2017).

26. Santos, C. H. S., Piccoli, R. H. \& Tebaldi, V. M. R. Antimicrobial activity of the essential oils and isolated compounds on the hospital-borne and foodborne pathogens. Rev Inst Adolfo Lutz. São Paulo 76, e1719 (2017).

27. Feng, Y. et al. Evolution and pathogenesis of Staphylococcus aureus: lessons learned from genotyping and comparative genomics. FEMS Microbiol. Rev. 32, 23-37 (2008).

28. Mesa-Arango, A. C. et al. Citral and carvone chemotypes from the essential oils PF Colombian Lippia Alba (Mill.) N.E. Brown: Composition, cytotoxicity and antifungal activity. Mem. Inst. Oswaldo Cruz 104, 878-884 (2009).

29. Nazzaro, F., Fratianni, F., De Martino, L., Coppola, R. \& De Feo, V. Effect of essential oils on pathogenic bacteria. Pharmaceuticals (Basel) 6, 1451-1474 (2013).

30. Rocha, L. Q. Interferência do óleo essencial de folhas do quimiotipo II de Lippia alba (MILL.) NE BROWN na atividade antimicrobiana da oxacilina sobre Staphylacoccus aureus oxacilina-resistente. in 127 f. Dissertação (Mestrado em Ciências Farmacêuticas)_Universidade Federal do Ceará. (Faculdade de Farmácia, Odontologia e Enfermagem, Fortaleza, 2012).

31. Sales, G. W. P., Batista, A. H. M., Rocha, L. Q. \& Nogueira, N. A. P. Efeito antimicrobiano e modulador do óleo essencial extraído da casca de frutos da Hymenaea courbaril L. Rev. Ciênc. Farm. Básica Apl. 35, 709-715 (2014).

32. McCarthy, H. et al. Methicillin resistance and the biofilm phenotype in Staphylococcus aureus. Front. Cell. Infect. Microbiol. 5, 1 (2015).

33. de Carvalho, C. C. \& da Fonseca, M. M. Preventing biofilm formation: Promoting cell separation with terpenes. FEMS Microbiol. Ecol. 61, 406-413 (2007).

34. Silva, L. N., Zimmer, K. R., Macedo, A. J. \& Trentin, D. S. Plant natural products targeting bacterial virulence factors. Chem. Rev. 116, 9162-9236 (2016).

35. Aiemsaard, J., Aiumlamai, S., Aromdee, C., Taweechaisupapong, S. \& Khunkitti, W. The effect of lemongrass oil and its major components on clinical isolate mastitis pathogens and their mechanisms of action on Staphylococcus aureus DMST 4745. Res. Vet. Sci. 91, e31-e37 (2011).

36. Valliammai, A. et al. Proteomic profiling unveils citral modulating expression of IsaA, CodY and SaeS to inhibit biofilm and virulence in methicillin-resistant Staphylococcus aureus. Int. J. Biol. Macromol. 158, 208-221 (2020).

37. Nuryastuti, T. et al. Effect of cinnamon oil on icaA expression and biofilm formation by Staphylococcus epidermidis. Appl. Environ. Microbiol. 75, 6850-6855 (2009).

38. Espina, L., Pagán, R., López, D. \& García-Gonzalo, D. Individual constituents from essential oils inhibit biofilm mass production by multi-drug resistant Staphylococcus aureus. Molecules 20, 11357-11372 (2015).

39. Jafri, H., Husain, F. M. \& Ahmad, I. Therapeutic sciences antibacterial and antibiofilm activity of some essential oils and compounds against clinical strains of Staphylococcus aureus. J. Biomed. Ther. Sci. 1, 65-71 (2014).

40. Lloyd, J. M. D. H. \& Lindsay, J. A. Staphylococcus aureus host specificity: Comparative genomics of human versus animal isolates by multistrain microarray L-sung. J. Microbiol. 154, 1949-1959 (2008).

41. Ma, Y. et al. Novel inhibitors of Staphylococcus aureus virulence gene expression and biofilm formation. PLoS ONE 7, e47255 (2012).

42. Rutherford, S. T. \& Bassler, B. L. Bacterial quorum sensing: Its role in virulence and possibilities for its control. Cold Spring Harb. Perspect. Med. 2, 1-25 (2012).

43. Joo, H. S., Chan, J. L., Cheung, G. Y. C. \& Otto, M. Subinhibitory concentrations of protein synthesis-inhibiting antibiotics promote increased expression of the agr virulence regulator and production of phenol-soluble modulin cytolysins in community-associated methicillin-resistant Staphylococcus aureus. Antimicrob. Agents Chemother. 54, 4942-4944 (2010).

44. Davies, J., Spiegelman, G. B. \& Yim, G. The world of subinhibitory antibiotic concentrations. Curr. Opin. Microbiol. 9, 445-453 (2006).

45. Azizkhani, M. \& Parsaeimehr, M. Effects of Cinnamomum zeylanicum and Ocimum basilicum essential oils on the growth of Staphylococcus aureus ATCC 29213 and gene expression of enterotoxins A, C and E. J. Essent. Oil Res. 27, 506-513 (2015).

46. de Almeida, J. B. et al. Detection, antibiotic resistance, and pathogenicity of staphylococci in samples from a Brazilian human milk bank. Breastfeed. Med. 9, 557-558 (2014).

47. de Carvalho, S. P. et al. Community-acquired methicillin-resistant Staphylococcus aureus carrying SCCmec type IV and V isolated from healthy children attending public daycares in northeastern Brazil. Braz. J. Infect. Dis. 21, 464-467 (2017).

48. Adukwu, E. C., Allen, S. C. \& Phillips, C. A. The anti-biofilm activity of lemongrass (Cymbopogon flexuosus) and grapefruit (Citrus paradisi) essential oils against five strains of Staphylococcus aureus. J. Appl. Microbiol. 113, 1217-1227 (2012).

49. Adukwu, E. C., Bowles, M., Edwards-Jones, V. \& Bone, H. Antimicrobial activity, cytotoxicity and chemical analysis of lemongrass essential oil (Cymbopogon flexuosus) and pure citral. Appl. Microbiol. Biotechnol. 100, 9619-9627 (2016).

50. Yatsuda, R. et al. Effects of Mikania genus plants on growth and cell adherence of mutans streptococci. J. Ethnopharmacol. 97, 183-189 (2005).

51. Clinical and Laboratory Standards Institute. Performance Standards for Antimicrobial Susceptibility Testing; Twenty-Second Informational Supplement. CLSI Document m100- S22. (Clinical and Laboratory Standards Institute, 2020).

52. Oliveira, P. S. et al. Isolation, pathogenicity and disinfection of Staphylococcus aureus carried by insects in two public hospitals of Vitória da Conquista, Bahia. Brasil. Braz. J. Infect. Dis. 18, 129-136 (2014).

53. Lewis, K. Riddle of biofilm resistance. Antimicrob. Agents Chemother. 45, 999-1007 (2001).

54. Takahashi, N., Ishihara, K., Kato, T. \& Okuda, K. Susceptibility of Actinobacillus actinomycetemcomitans to six antibiotics decreases as biofilm matures. J. Antimicrob. Chemother. 59, 59-65 (2007).

55. Coelho, L. R. et al. agr RNAIII divergently regulates glucose-induced biofilm formation in clinical isolates of Staphylococcus aureus. Microbiology (Reading) 154, 3480-3490 (2008). 
56. Lee, Y. D., Moon, B. Y., Park, J. H., Chang, H. I. \& Kim, W. J. Expression of enterotoxin genes in Staphylococcus aureus isolates based on mRNA analysis. J. Microbiol. Biotechnol. 17, 461-467 (2007).

57. Korem, M., Gov, Y. \& Rosenberg, M. Global gene expression in Staphylococcus aureus following exposure to alcohol. Microb. Pathog. 48, 74-84 (2010).

58. Johnson, W. M. et al. The detection of enterotoxins and toxic shock syndrome toxin genes in Staphylococcus aureus by polymerase chain reaction. J. Clin. Microbiol. 29, 426-430 (1991).

59. Abdelhady, W. et al. Early agr activation correlates with vancomycin treatment failure in multi-clonotype MRSA endovascular infections. J. Antimicrob. Chemother. 70, 1443-1452 (2015).

\section{Acknowledgements}

Jim Hesson copyedited the manuscript (https://www.academicenglishsolutions.com).

\section{Author contributions}

Conceived and designed the experiments: H.B.M.O., G.B.C., J.T., A.P.T.U., R.Y., and L.M.M. Determination of minimum inhibitory concentration (MIC), minimum bactericidal concentration (MBC), and subinhibitory dose assays: H.B.M.O., N.N.S., B.A.S., S.P.C., J.B.A., and T.L.S.B. Citral interference in antibiotics assay: H.B.M.O., N.N.S., B.A.S., S.P.C., J.B.A., L.O.S., M.M.T., H.I.L.N.C., C.D.B., R.S.B., J.C.S.V. and T.L.S.B. Biofilm assay: H.B.M.O., N.N.S., B.A.S., M.N.S.J., C.N.T.O., and P.P.A. Virulence gene expression: H.B.M.O., B.A.S., T.L.S.B., Y.M.F.S.A., M.N.S.J., C.N.T.O., G.B.C., and L.M.M. Analyzed the data: H.B.M.O., I.B.S.S., G.B.C., R.Y., A.P.T.U., J.T., and L.M.M. Contributed reagents/materials/analysis tools: J.T., R.Y., A.P.T.U., and L.M.M. Wrote the paper: H.B.M.O., G.B.C., R.Y., A.P.T.U., and L.M.M. All authors read and approved the final manuscript.

\section{Funding}

This study was supported by Fundação de Amparo em Pesquisa do Estado da Bahia (JCB0035/2016) and Coordenação de Aperfeiçoamento de Pessoal de Nível Superior (CAPES-Code 001), Brazil. The funding agencies played no role in the design or conclusion of the study.

\section{Competing interests}

The authors declare no competing interests.

\section{Additional information}

Correspondence and requests for materials should be addressed to L.M.M.

Reprints and permissions information is available at www.nature.com/reprints.

Publisher's note Springer Nature remains neutral with regard to jurisdictional claims in published maps and institutional affiliations.

(c) (i) Open Access This article is licensed under a Creative Commons Attribution 4.0 International License, which permits use, sharing, adaptation, distribution and reproduction in any medium or format, as long as you give appropriate credit to the original author(s) and the source, provide a link to the Creative Commons licence, and indicate if changes were made. The images or other third party material in this article are included in the article's Creative Commons licence, unless indicated otherwise in a credit line to the material. If material is not included in the article's Creative Commons licence and your intended use is not permitted by statutory regulation or exceeds the permitted use, you will need to obtain permission directly from the copyright holder. To view a copy of this licence, visit http://creativecommons.org/licenses/by/4.0/.

(C) The Author(s) 2021 